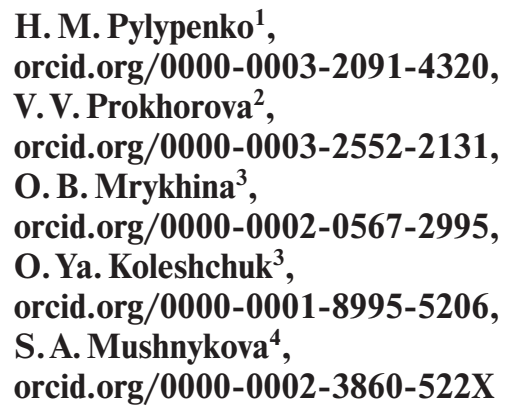

1 - Dnipro University of Technology, Dnipro, Ukraine, e-mail: annapylyp@ukr.net

2 - Ukrainian Engineering Pedagogics Academy, Kharkiv, Ukraine

3 - Lviv Polytechnic National University, Lviv, Ukraine

4 - National Metallurgical Academy of Ukraine, Dnipro, Ukraine

\title{
COST EVALUATION MODELS OF R\&D PRODUCTS OF INDUSTRIAL ENTERPRISES
}

Purpose. To develop a pricing model for R\&D products of industrial enterprises that would meet the changing conditions of the market environment.

Methodology. The research was based on a set of methods, including comparative analysis, which was used to compare existing approaches to pricing for R\&D products; Mamdani algorithm of fuzzy set theory to develop a methodology for forming the price of R\&D products taking into account their consumer value and market receptivity; matrix method - to determine the level of the average market price for $R \& D$ products.

Findings. The existing methodological approaches to pricing in the market of R\&D products of industrial enterprises are analyzed; their advantages and limitations are highlighted. A methodology for pricing R\&D products has been developed which allows us to take into account their consumer value and market receptivity. The matrix method for determining the level of the average market price for R\&D product is explained. Based on the authors' approach, comparison of the prices of R\&D products with the prices of their market counterparts was conducted. The probability level of the obtained results is estimated using the example of R\&D products of LLC “Diada Group”.

Originality. A model of pricing for R\&D products is developed. It is based on the methodology of forming the price of R\&D product taking into account its consumer value and market receptivity, the matrix method for forming the average market price of $\mathrm{R} \& \mathrm{D}$ products, and the approach to comparing the obtained showings with the prices of market analogs. In contrast to the wellknown ones, such a comprehensive approach allows us to achieve a higher level of price accuracy, since a set of heterogeneous features of factors influencing the price of $R \& D$ product is taken into account (by developing a correction factor based on the Mamdani algorithm of fuzzy set theory). The approach to the formation of features of factors influencing the price of R\&D product makes it possible to maneuver the composition of R\&D product features.

Practical value. The authors' pricing model for R\&D products was tested at LLC "Diada Group" and demonstrated high possibilities to improve the accuracy of price formation in the reality of changing market. Being a fairly flexible pricing tool, this model can be applied in the practical activities of enterprises in various sectors of the economy.

Keywords: $R \& D$ product, pricing models for $R \& D$ products, commercialization of innovations, competitiveness, knowledge intensity

Introduction. The current state of socio-economic development, which is characterized by a radical change in the technical and technological paradigm within a globalized world, is marked by new phenomena and processes. In contrast to previous eras, where the formation of new technological methods of production was based on a small number of breakthrough inventions that changed the structure of production, today we are witnessing an avalanche of invention, the products of which destroy the stability of all spheres of society.

The relative predictability of innovative development inherent in the world economy a few decades ago and described by M. Kondratiev (M. Kondratiev, 1928), S. Kuznets (S. Kuznets, 1971), G. Mensch (G. Mensch, 1975), Ch. Freeman, Y.Clark and L. Soete (Ch. Freeman, Y.Clark \& L. Soete, 1982), Y.van Duijin (Y.van Duijin, 1983) and other researchers, is proved difficult to achieve in modern conditions. The shortening of the life cycle of generations of equipment and technologies, the pulse-like nature of the cyclicity of innovative renewal of production (for example, in the field of industrial electronics, the intervals between the generation of breakthrough innovations have reduced to $2-4$ years) requires innovators to respond almost instantly to changes in the global market conditions. Today, more than ever, it is of particular importance to create approaches that would help to quickly assess the situation and create a price for $R \& D$ products that would ensure the profitability of the innovative business in an

(C) Pylypenko H.M., Prokhorova V.V., Mrykhina O.B., Koleshchuk O. Ya., Mushnykova S. A., 2020 extremely unstable market environment. The success of the further transfer, commercialization, and market launch of $\mathrm{R} \& \mathrm{D}$ products depends on the correct pricing model. This, in turn, has a significant impact on the pace of the innovative development of the country. The latter is highlighted in the Global Competitiveness Report [1] and the preamble to the International Valuation Standards 2020 [2], and European Valuation Standards 2020 [3].

Literature review. Pricing issues for $R \& D$ products arouse considerable interest from scientists and experts. In particular, C. Borgs and a group of scientists created a computer system that makes it easier to set prices for goods due to the presence of a clustering element [4]. S. Morenoa and D. Epstein offer approaches to determining prices for innovative products of pharmaceutical companies [5]. P. Chwastyk and M. Kolosowski proposed methods to estimate the cost of planning, development, and activities in the R\&D sector [6]. Some methodological aspects of the evaluation of $R \& D$ products are given in the work by F. Barillas and J. Shanken, who compared the most common asset pricing models and proposed a testing procedure for determining prices [7]. Elements of the R\&D product evaluation are given in part in O. Matushevska and N. Katkova [8], where proposals were developed to improve the efficiency of ensuring the economic stability of industrial enterprises in Ukraine.

A certain number of scientific papers are devoted to the economic evaluation of $R \& D$ products from a macroeconomic perspective. For example, D. Kiselakova, B. Sofrankova, and co-authors offer their own view on solving the problem of 
R\&D in the development of global competitiveness on the example of Slovakia [9], while M. Wang's work deals with methods for evaluating and applying academic technologies in Taiwan [10].

Despite a significant scientific background, the real activity of business entities in the field of $R \& D$ continues to generate problems that need to be solved. Thus, for companies that create innovative products, there are still relevant issues of creating a price formation tool that would meet the modern requirements of the changing market and would be effective for both developers and consumers. This issue is particularly important for industrial electronics enterprises, where the most promising economic activities are concentrated today and whose products form the technical and technological potential of the country's economy.

It should be noted that the existing approaches to ensuring pricing for R\&D products are mainly based on quantitative assessment methods. This complicates management decisionmaking processes, which must take into account the variability of market conditions. Expert methods also do not provide an effective basis for justifying the price of $R \& D$ products. A combination of quantitative and expert methods is needed to ensure a comprehensive approach to pricing for R\&D products.

Purpose. This work purpose is to create a pricing model for $R \& D$ products of industrial enterprises that would meet the changing conditions of the market environment.

Results. The theoretical and methodological basis of the vision of innovative development is presented in [11], and the sources for the development of methods and models for the valuation of $R \& D$ products is carried out in [12], where, in particular, a matrix approach to market pricing is developed. The basics of evaluating innovative technologies in the digital economy are explained in [13]. Based on these previous studies, as well as empirical data on the pricing of $R \& D$ products, we have formed three hypotheses, which were tested by directly evaluating various $R \& D$ products from the field of industrial electronics.

Hypothesis 1. The authors' pricing model for R\&D products will contribute to obtaining reasonable results since it makes it possible to aggregate and account for a heterogeneous set of factors influencing $R \& D$ products.

Hypothesis 2. The characteristics of generalizing factors influencing the price of $R \& D$ products that are used in the authors' model are universal, suitable for pricing purposes in the case of any type of $R \& D$ products.

Hypothesis 3. The authors' methods of price adjustment for R\&D products are suitable for pricing purposes in short, medium- and long-term periods.

It should be noted that several documents regulating general approaches to the valuation of $R \& D$ products have been developed in the world practice. The main groups are International Valuation Standards (IVS) [2] and European Valuation Standards (EVS) [3]. The role of these groups of standards is defining because they are part of the international legal and regulatory framework (Directives and Regulations of the European Union). Important for evaluation purposes are the three, presented in EVS, European Business Valuation Guidance Notes (EBVGN), which follow from EVS and provide more detailed information and explanations on the main issues and evaluation techniques.

In Ukraine, the evaluation of $R \& D$ products should be made in concordance with IVS and EVS and be carried out on the principles of national standards approved at the state level. Pricing is based on the assessment of the cost of R\&D products, and therefore, similar methodological approaches are used, which are cost-based, revenue, comparative (market), and combined. In Ukraine, they are approved by the Resolution of the Cabinet of Ministers of Ukraine dated 03.10.2007 No. 1185 [14] (with amendments and additions). These approaches are represented by different types of methods.
Traditionally, companies' price formation for R\&D products is based on a cost-based methodological approach, taking into account all types of costs incurred by the developer (enterprise) during the creation of this $R \& D$ product. In this case, various methods of cost-based approach can be applied (in particular, replacement cost, initial cost, cost gain, coefficient, and others). The cost-based approach methods are based on the economic principles of substitution and price equilibrium and provide fairly accurate results for pricing purposes.

Cost-based approach methods are most often used during the basic evaluation of $R \& D$ products, the formation of cost estimates for research and development work based on R\&D product data, and so on. Often, the cost-based approach is used to determine the value of $R \& D$ products in order to transfer them to the assets of a business entity and increase its market value.

On the one hand, determining the price based on the costbased approach is less risky than other approaches, since it is based only on the actual costs of the developer. However, on the other hand, the price set by this approach may not reflect the actual place of a particular R\&D product among competitive products during its market launch. This price also does not take into account the future benefits of using the R\&D product, social standards, and moral tear of the R\&D product (in particular, if the R\&D product is developed for a long period of time - more than five years). The approach also does not take into account the risks of the licensee obtaining economic benefits from the $R \& D$ product.

The total cost of developing an $R \& D$ product is primarily used as a source for determining the break-even point of a given $R \& D$ product. In other words, such methods can only show the "lower limit" of the R\&D product price, which will require further adjustment to take into account market conditions (consumer requests, market trends, the appearance of technology characteristics after its market launch, and so on). This reduces the effectiveness of using cost-based approach methods in pricing for $\mathrm{R} \& \mathrm{D}$ products.

The revenue methodology approach allows us to set the price of an R\&D product as the present price of future economic income that is associated with the ownership of this R\&D product over its estimated cycle of life. Among the methods of this approach are: the discounted cash flow method, royalty method, real license fees, method of profit capitalization, method of excessive income, and others. The price of an $R \& D$ product based on the methods of this approach is formed by calculating the present price of the projected future benefits. The application of the revenue approach is based on determining the amount of profit that can bring an R\&D product, as well as capitalization rates that take into account the risk associated with the return of an R\&D product. The complexity of applying revenue approach methods for an $R \& D$ product is due to a significant level of subjectivity in the justification of cash flows, which are often determined by the place of application of this R\&D product. In general, this methodological approach is universal, making it possible to determine exactly the cost of an R\&D product, which should be set according to the scenario of the commercialization of the $R \& D$ product. The disadvantage of the revenue approach is the difficulty of obtaining initial information for pricing $\mathrm{R} \& \mathrm{D}$ products.

The comparative (market) methodological approach to pricing for $\mathrm{R} \& \mathrm{D}$ products is represented by the following methods: cost of acquisition, comparative sales, expert assessments, and so on. The application of the approach is the process of evaluating the market value of an $R \& D$ product by comparing similar R\&D products and comparing them with the evaluated R\&D product. The "downside" of the comparative approach is blurring the uniqueness of the R\&D product, since objects with similar consumer value will have similar prices. Effective application of the comparative methodological approach is possible if estimators are able to collect an ar- 
ray of diverse information (production, market, financial, etc.) not only on the R\&D product in question but also numerous analogs.

Among the disadvantages of this approach, we should note the complexity of mutual understanding between the parties of the concept of comparability of R\&D products and their analogs, lack of consideration of the prospects for the development of R\&D product, the need to make complex price adjustments for R\&D product, and so on. The problem areas that can arise when pricing $R \& D$ products using a comparative methodological approach are that transfer transactions with comparable R\&D products in the market are usually limited to two or three enterprises or even divisions of a single enterprise. Prices for R\&D products (in particular, transfer prices) are mostly a trade secret and are not subject to official disclosure. Although most R\&D products are unique, the comparative methodological approach is not widely used for them. However, in the field of industrial electronics, sufficient information can be obtained to apply this approach.

A significant advantage of the comparative methodological approach is to take into account the probabilistic nature of the R\&D product price, which depends on many dynamic factors. Along with other methods, the methods of this approach most effectively reflect the demand and supply for an R\&D product, taking into account the market situation as much as possible.

A combined approach to pricing for $R \& D$ products can integrate all of the above approaches. Among the methods of the combined approach, there is the method of environmental and social assessment, the method of weight contributions of the market, cost-based and revenue approaches to the final result, and others.

Due to the exclusivity of R\&D products, the complexity of searching for analog objects, the variety of specific characteristics of $\mathrm{R} \& \mathrm{D}$ products, the conditions for their generation, implementation, and use, in practice, it is necessary to determine prices for such R\&D products based on the methods of several methodological approaches. At the same time, the price of an $\mathrm{R} \& \mathrm{D}$ product should be formed taking into account market categories, namely: demand, supply, competition, and other market factors that directly or indirectly affect the pricing processes, along with an assessment of the key characteristics of $\mathrm{R} \& \mathrm{D}$ products.

Taking into account the changing market conditions and the uniqueness of each $R \& D$ product, the price formation for it should take into account the heterogeneous parameters of consumer value and its market receptivity. These two characteristics comprehensively describe the R\&D product, on the basis of which you can form an idea of the prospects for its commercialization, market launch, diffusion, and so on. Based on the aggregation of parameters that determine the specifics of the consumer value and market receptivity of an R\&D product, you can output a correction factor that will allow you to clarify the current price for the $R \& D$ product (for example, pre-formed by the cost-based method), which can later be compared with the price of the market analog of this $\mathrm{R} \& \mathrm{D}$ product.

However, if the theoretical relationship between the consumer value of an $\mathrm{R} \& \mathrm{D}$ product and its market receptivity is obvious, then it is not an easy task to justify an econometric model for determining such a correction factor, since the set of parameters that determine the consumer value and market receptivity of an R\&D product is quite diverse, with a complex level of mutual correlation. Therefore, to develop a correction factor to clarify the price of an R\&D product, taking into account its consumer value and market receptivity, it is advisable to use fuzzy set theory algorithms. Models based on these principles (in particular, Mamdani, Larsen, Tzukamoto, Sugeno, and others) have a high level of flexibility in minding expert assessments that are highly adaptable in practical application and contribute to the formalization of different types of dependencies.
By adjusting prices for R\&D products based on fuzzy sets, we should understand the process by which, based on an existing set of data, we can establish significant parameters that determine the nature of the $R \& D$ product valuation and make it possible to analyze changes in its states that are not directly measured. The methodology for applying fuzzy set theory algorithms to evaluate economic phenomena is based on some theoretical foundations by L. Zadeh (L. Zadeh, 1976), in particular:

1) assume that the $R \& D$ product will enter the state that applies to a finite set of states $S$ where there are two disjoint subsets $S_{1} \cup S_{2}\left(S_{1}\right.$ is a subset of the states in the degree of manifestation of signs are consistent with the parameters of the desired state; $S_{2}$ is a subset of the states in the degree of manifestation of signs are not consistent with parameters desired state. The subset $S_{1}=\left\{s_{i}\right\}, i=\overline{1, n}$ includes the types of states that contribute to effective development. The subset $S_{2}=\left\{s_{j}\right\}, i=\overline{1, m}$ includes types of states that correspond to changes in parameters or their relationships that lead to deviations from the expected result;

2) we analyze sets $S$ or subsets $S_{1}$ and $S_{2}$ as the basis for evaluating the real state of an object. The assessment is based on expert assessments and methods for its conduction;

3 ) we detect deviations from the parameters of the desired state (that is, the object can be in a state of transformation from the state $S_{k}$ to $S_{l}$, since the conditions are not violated if $S_{k}$ and $S_{l}$ belong to a subset of states $S_{1}$ ).

The criterion of cost efficiency in R\&D product based on consumer values $R \& D$ product and market receptivity based on the algorithms of the theory of fuzzy sets is expressed by the maximization of the suitability level of the results obtained (estimates of) a particular market situation.

For the most part, $R \& D$ products are characterized by a significant level of innovation, which determines the level of their consumer value. At the same time, the consumer value may not be sufficient if the market receptivity of this product is low. On the one hand, consumer value is a response to market expectations or requests, and on the other - consumers may not be ready to purchase this $R \& D$ product. We believe that integrating these two mutually conditioned characteristics of an R\&D product into a single correction factor using fuzzy set theory algorithms to form the price of the $R \& D$ product will help clarify the place of the R\&D product in the market, form an adequate price for it, and achieve a high degree of predictability of market effects that an R\&D product may entail. The price for an R\&D product formed in this way will be reasonable since it will simultaneously take into account the characteristics of the R\&D product that determine its consumer value and the signs of a changing market that will indicate the level of its receptivity.

In order to develop the above-described price adjustment coefficient for R\&D products based on fuzzy set theory algorithms, the Mamdani model was selected. This model differs from others in the fact that its rules contain fuzzy values (membership functions) in their consequents. According to the Mamdani model, it is advisable to divide the process of price adjustment for R\&D products into stages that are characterized by such mathematical content:

1) fuzzification (determining possible values of linguistic variables);

2) generalization of antecedents and consequents, forming conclusions using logical connections;

3) de-fuzzification.

Based on the conducted research, lists of features of generalizing factors influencing the price $\left(x_{1}-\right.$ features that determine the consumer value of an R\&D product, $x_{2}$ - features that determine the market receptivity of an $R \& D$ product) are formed, which will adjust the price of R\&D products. The attributes are summarized in Table 1, where they are assigned the value of linguistic variables. 
Signs and factors influencing the price of R\&D products

\begin{tabular}{|c|c|c|}
\hline $\begin{array}{l}\text { Generalizing factors influencing } \\
\text { the price of an R\&D product } \\
\text { (thermal peaks) }\end{array}$ & Signs of factors influencing the price & $\begin{array}{l}\text { Meaning and explanation of } \\
\text { linguistic terms of the factor }\end{array}$ \\
\hline \multirow{8}{*}{$\begin{array}{l}x_{1}-\text { features that determine the } \\
\text { consumer value of an R\&D } \\
\text { product }\end{array}$} & The level of competitiveness of an $\mathrm{R} \& \mathrm{D}$ product $\left(p_{1}\right)$ & \multirow{13}{*}{$\begin{array}{l}\mathrm{L}-\text { low indicator level } \\
{[-50 ;-40 ;-30] ;} \\
\text { E - entertainable indicator } \\
\text { level }[-30 ;-20 ;-10] ; \\
\mathrm{M}-\text { middle indicator level } \\
{[-10 ; 0 ; 10] ;} \\
\text { A - available indicator level } \\
{[10 ; 20 ; 30] ;} \\
\text { H - high indicator level } \\
{[30 ; 40 ; 50]}\end{array}$} \\
\hline & The level of technological readiness of an R\&D product $\left(p_{2}\right)$ & \\
\hline & The level of the knowledge intensity of an R\&D product $\left(p_{3}\right)$ & \\
\hline & The legal protection level of an R\&D product $\left(p_{4}\right)$ & \\
\hline & The level of key competencies of the R\&D product development team $\left(p_{5}\right)$ & \\
\hline & The level of social orientation of an R\&D product $\left(p_{6}\right)$ & \\
\hline & The level of environmental friendliness of an R\&D product $\left(p_{7}\right)$ & \\
\hline & The security level of an R\&D product $\left(p_{8}\right)$ & \\
\hline \multirow{5}{*}{$\begin{array}{l}x_{2}-\text { signs that determine the } \\
\text { market receptivity of an R\&D } \\
\text { product }\end{array}$} & The scaling potential level of an $\mathrm{R} \& \mathrm{D}$ product $\left(p_{9}\right)$ & \\
\hline & The market convergence level of an R\&D product $\left(p_{10}\right)$ & \\
\hline & The risk level of an R\&D product $\left(p_{11}\right)$ & \\
\hline & The level of market diffusion of an R\&D product $\left(p_{12}\right)$ & \\
\hline & The level of complexity of the market launch of an R\&D product $\left(p_{13}\right)$ & \\
\hline
\end{tabular}

The approach to $R \& D$ product price adjustment using fuzzy set theory algorithms can be described as a function: $S=$ $=f\left(x_{1} ; x_{2}\right)$, which is a system of functions in the following order (notation according to Table 1)

$$
\left\{\begin{array}{l}
f\left(x_{1}\right)=f\left(p_{1} ; p_{2} ; p_{3} ; p_{4} ; p_{5} ; p_{6} ; p_{7} ; p_{8}\right) \\
f\left(x_{2}\right)=f\left(\left(p_{9} ; p_{10} ; p_{11} ; p_{12} ; p_{13}\right)\right.
\end{array} .\right.
$$

In practice, the existing characteristics of factors influencing the price of $R \& D$ products form a questionnaire for experts. Each attribute is assigned a score in points: from -2 to 2 (where "-2" - no influence features, "-1" - a low degree of influence, " 0 " - an average degree of influence, " 1 " - a high degree of influence, "2" - the highest degree of influence). Experts evaluate the characteristics of an R\&D product, and then their judgments are matched using a concordance coefficient. It should be noted that in the case of evaluating each specific $R \& D$ product, the characteristics may objectively have a different level of manifestation, which is advisable to correct using weight coefficients. Using the method for determining the arithmetic mean, we derive the total score for a group of factors from the estimates obtained by generalizing factors $x_{1}$ and $x_{2}$ and convert the resulting number to a percentage $(\%)$. Moving further, we evaluate which range of values of the linguistic terms of the factor belongs to the obtained estimate. Based on the formed set of term factors, it is necessary to develop a knowledge base - possible variants of the ratio of characteristics on the impact on the consumer value of an $\mathrm{R} \& \mathrm{D}$ product $-x_{1}$ and market receptivity $-x_{2}$. If necessary, it is advisable to apply the weight of the rule in the range $[0 \ldots 1]$, which will indicate the significance level of the variant of generalizing factors influencing the price of $R \& D$ product ratio.

Based on the application of the Mamdani algorithm in the Fuzzy Logic Toolbox component of the MATLAB software package, a model was created for adjusting the price of an R\&D product using the authors' method described, and a knowledge base was added, a fragment of which is shown in Fig. 1.

A change in the level of a particular trait within $x_{1}$ or $x_{2}$ means a change in the level of consumer value and market sensitivity of the R\&D product due to this trait. In turn, this affects the adjustment of the $R \& D$ product price indicator.

A visualization of a fuzzy model of price adjustment for $\mathrm{R} \& \mathrm{D}$ products for pricing purposes, reflecting the relationship between consumer value influences and market receptivity of $\mathrm{R} \& \mathrm{D}$ products, is shown in Fig. 2. Within the described system, the resulting surface is a reference.

The method was developed and tested on the example of a number of R\&D products of LLC “Diada Group”, which works in the field of industrial electronics. It should be noted that the functions of belonging of fuzzy subsets to a fuzzy set the R\&D product price correction coefficient - are formed so that this coefficient has a value in the range from 0 to 100 . Defuzzification was performed using the centroid method.

Programming within the Fuzzy Logic Toolbox MATLAB component for generalizing factors influencing the price of the R\&D product of LLC "Diada Group" and further de-fuzzification allowed us to obtain the desired correction factors for pricing purposes. An example of the result of the servo conversion technology of DC is shown in Fig. 3.

This method was used to calculate correction factors for a number of R\&D products of LLC "Diada Group". As a result of applying a reasonable method, the obtained values are determined by a fuzzy number with a certain range, which allows us to apply not only probabilistic estimates but also design parameters. The method allows you to achieve a higher level of accuracy of the $R \& D$ product price indicator since it takes into

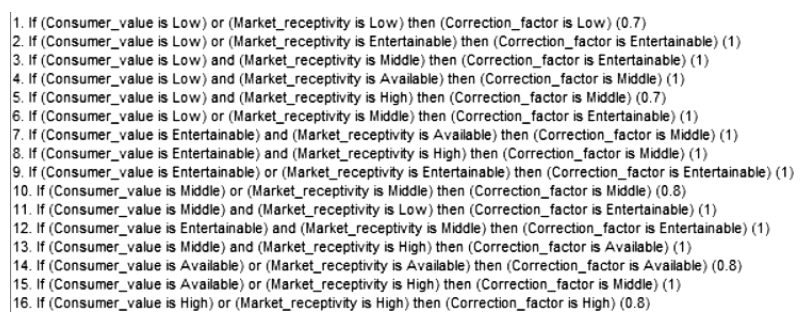

Fig. 1. Creating a knowledge base for the $R \& D$ product price adjustment model using the Mamdani algorithm in the Fuzzy Logic Toolbox MATLAB component (fragment)

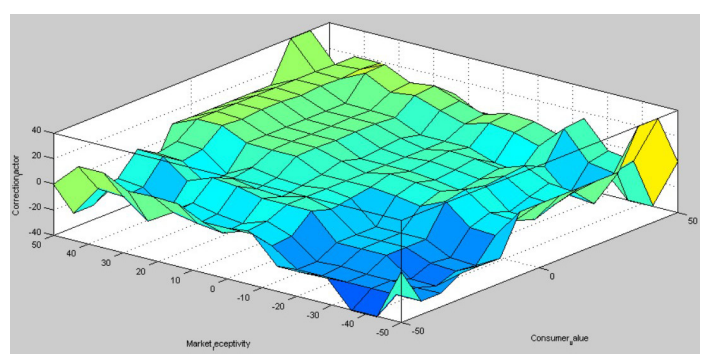

Fig. 2. Reference surface of the correlation system of consumer value influences and market receptivity of an $R \& D$ product 


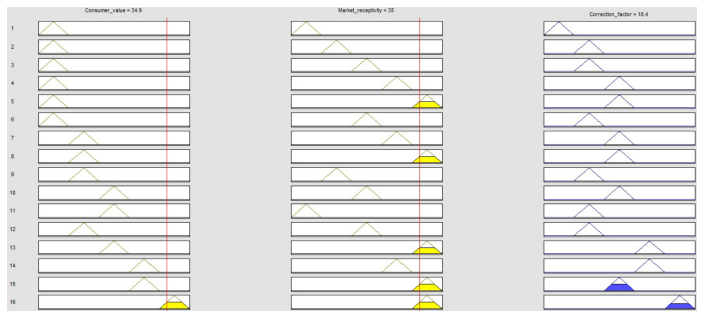

Fig. 3. Results of determining the correction factor for ricing purposes for the DC servo conversion technology $L L C$ " $D i$ ada Group" using Fuzzy Logic Toolbox MATLAB

account a set of features characteristic of the R\&D product and the changing market situation.

Among the most common approaches to pricing for R\&D products is the comparative one.

According to the Methods of evaluation of intellectual property rights (Order of the State Property Fund, 2008, No. 740), the price of an R\&D product is formed by adjusting the sale prices (offers) similar objects arising from the contracts, the essential terms of which meet or will meet the conditions to determine the market value of the development [15].

The methods of the comparative approach provide the basis for setting the average market price for an $R \& D$ product. When applying a comparative approach to pricing, it is important to take into account reliable data relative to analogs, as well as the mutual correlation between the characteristics of the objects being compared. It is necessary to operate with objective estimates, which requires formalization, in particular in terms of adjusting the price of an $R \& D$ product by indicators of similar or different analogs (which reflect the manifestation of consumer value and market receptivity of the $R \& D$ product, which was mentioned above).

To generate a price for an R\&D product based on a comparative methodological approach, we use the expression

$$
V_{i n t}=V_{a}+\sum_{j=1}^{m} \cdot \Delta V_{a j},
$$

where $V_{\text {int }}$ is the price of an R\&D product, gr. units; $V_{a}$ is the price of a similar R\&D product, gr. units; $m$ is the number of features to compare $\Delta V_{a j}$ is correction in the price $(+,-)$ of the sale of a similar R\&D product, for the $j^{\text {th }}$ comparison feature.

In part, the method for evaluating developments using a comparative approach was revealed in [12], which will have its peculiarities for pricing tasks for R\&D products.

To compare an R\&D product with similar objects, a system of equations is formed, which, taking into account the adjustment, we will describe as follows

$$
\left\{\begin{array}{l}
V_{\text {int }}-\Delta x_{11} \cdot \Delta V_{1}-\Delta x_{12} \cdot \Delta V_{2}-\ldots-\Delta x_{1 n} \cdot \Delta V_{n} \\
V_{\text {int }}-\Delta x_{21} \cdot \Delta V_{1}-\Delta x_{22} \cdot \Delta V_{2}-\ldots-\Delta x_{2 n} \cdot \Delta V_{n} \\
V_{\text {int }}-\Delta x_{31} \cdot \Delta V_{1}-\Delta x_{32} \cdot \Delta V_{2}-\ldots-\Delta x_{3 n} \cdot \Delta V_{n} \\
\ldots \ldots \ldots \ldots \ldots \ldots \ldots \ldots \ldots \ldots \ldots \ldots \ldots \ldots \ldots \ldots
\end{array},\right.
$$

where $x_{0 j}$ is the value $j$ of the correction coefficient for the object of evaluation; $x_{a j}$ is the value of the $j^{\text {th }}$ correction coefficient for the $a$-analogue; $\Delta V_{j}$ is contribution to the unit price of the $j^{\text {th }}$ correction factor.

In matrix form, system (3) will have a description

$$
\Delta X V^{\prime}=V ; \quad V^{\prime}=\left\{\begin{array}{c}
V_{\text {int }} \\
\Delta V_{1} \\
\ldots \\
\Delta V_{n}
\end{array}\right\} ; \quad V=\left\{\begin{array}{c}
V_{1} \\
V_{1} \\
\ldots \\
V_{m}
\end{array}\right\} ; \quad V^{\prime}=\Delta X^{-1} V,
$$

where $\Delta X^{-1}$ is inverse matrix to the $\Delta X$ matrix.

In order to determine the strength of the influence of factors that indicate the similarity or difference of the R\&D product from its analogs in terms of consumer value and market receptivity, a scale of impact factors was compiled: weak (03.3) medium (3.3-6.6), strong (6.6-10).

To test the described method of pricing for R\&D product, further calculations are shown on the example of the DC servo conversion technology of LLC "Diada Group". For this purpose, 14 analog objects were selected and the signs of factors

\begin{tabular}{|c|c|c|c|c|c|c|c|c|c|c|c|c|c|c|}
\hline \multirow{2}{*}{$\begin{array}{l}\text { R\&D product and its } \\
\text { market analogs }\end{array}$} & \multicolumn{13}{|c|}{ Evaluation of signs of factors influencing the price of $R \& D$ product analogs, points } & \multirow{2}{*}{$\begin{array}{l}\text { Prices, } \\
\text { thousand } \\
\text { UAH }\end{array}$} \\
\hline & $p_{1}$ & $p_{2}$ & $p_{3}$ & $p_{4}$ & $p_{5}$ & $p_{6}$ & $p_{7}$ & $p_{8}$ & $p_{9}$ & $p_{10}$ & $p_{11}$ & $p_{12}$ & $p_{13}$ & \\
\hline $\begin{array}{l}\text { DC servo conversion } \\
\text { technology }\end{array}$ & 9.4 & 7.3 & 3.4 & 8.5 & 5.6 & 6.2 & 1.9 & 5.6 & 7.1 & 6.3 & 5.0 & 6.9 & 3.5 & - \\
\hline 1 & 9.3 & 9.1 & 6.9 & 9.1 & 8.9 & 9.6 & 7.3 & 5.6 & 6.3 & 7.8 & 4.3 & 5.6 & 3.4 & 99.55 \\
\hline 2 & 8.4 & 7.2 & 1.9 & 3.9 & 4.2 & 3.9 & 5.1 & 7.1 & 6.3 & 7.1 & 2.1 & 4.5 & 7.2 & 69.77 \\
\hline 3 & 4.5 & 4.9 & 2.8 & 5.7 & 4.8 & 4.9 & 4.9 & 6.7 & 7.1 & 7.0 & 7.2 & 5.6 & 4.9 & 119.00 \\
\hline 4 & 8.9 & 9.0 & 8.4 & 8.9 & 8.9 & 9.4 & 7.1 & 3.9 & 4.5 & 5.9 & 6.0 & 7.8 & 7.1 & 11.52 \\
\hline 5 & 4.1 & 1.8 & 1.6 & 5.1 & 4.1 & 1.9 & 2.3 & 1.6 & 4.3 & 4.5 & 7.0 & 5.1 & 3.0 & 63.00 \\
\hline 6 & 6.9 & 7.1 & 3.0 & 4.0 & 5.2 & 4.8 & 3.2 & 6.3 & 4.5 & 5.1 & 6.3 & 5.6 & 4.5 & 83.56 \\
\hline 7 & 4.1 & 4.3 & 2.8 & 6.3 & 6.3 & 7.5 & 5.8 & 6.3 & 4.7 & 5.0 & 6.2 & 5.1 & 7.1 & 60.2 \\
\hline 8 & 5.8 & 4.9 & 1.7 & 4.9 & 4.1 & 5.7 & 1.5 & 2.2 & 5.7 & 6.7 & 8.9 & 6.1 & 4.2 & 71.6 \\
\hline 9 & 4.5 & 3.9 & 1.5 & 4.0 & 5.6 & 5.8 & 3.0 & 4.0 & 7.1 & 4.7 & 4.3 & 5.5 & 3.7 & 69.5 \\
\hline 10 & 8.4 & 7.1 & 1.5 & 4.1 & 4.5 & 5.0 & 5.9 & 6.0 & 7.1 & 7.1 & 3.4 & 3.9 & 8.0 & 71.92 \\
\hline 11 & 5.1 & 5.7 & 4.5 & 3.9 & 5.2 & 5.0 & 4.9 & 7.1 & 7.0 & 7.2 & 6.8 & 6.1 & 5.0 & 148.57 \\
\hline 12 & 9.1 & 9.0 & 8.4 & 8.9 & 8.9 & 9.4 & 7.1 & 3.9 & 4.0 & 6.1 & 6.2 & 8.0 & 6.0 & 12.03 \\
\hline 13 & 5.0 & 4.9 & 5.8 & 2.3 & 3.4 & 3.1 & 5.1 & 3.0 & 4.2 & 5.0 & 6.3 & 5.5 & 4.0 & 75.34 \\
\hline 14 & 6.0 & 8.2 & 4.5 & 6.1 & 5.8 & 6.7 & 7.1 & 6.0 & 4.3 & 7.1 & 8.0 & 4.5 & 3.9 & 91.84 \\
\hline
\end{tabular}
influencing the price from Table 1 were used. Table 2 is based on the influence of factors assessed by experts, coordination, and generalization of their opinions.

Table 2

Evaluation of characteristics of analogs of R\&D products - technologies of DC servo conversion of LLC "Diada Group"

* Analogues are products of companies: Siemens, "Dneproresurs” LTD and others 
Based on the data in Table 2, the matrices $\Delta X$ and $V$ are formed, the inverse matrix to $\Delta X$ is calculated, and this solution is obtained

$$
V^{\prime}=\left\{\begin{array}{c}
V_{\text {int }} \\
\Delta V_{1} \\
\Delta V_{2} \\
\Delta V_{3} \\
\Delta V_{4} \\
\Delta V_{5} \\
\Delta V_{6} \\
\Delta V_{7} \\
\Delta V_{8} \\
\Delta V_{9} \\
\Delta V_{10} \\
\Delta V_{11} \\
\Delta V_{12} \\
\Delta V_{13}
\end{array}\right\}=\left\{\begin{array}{c}
76.3451 \\
-4.5671 \\
11.2359 \\
-1.8321 \\
1.8021 \\
-14.1320 \\
8.4545 \\
3.0482 \\
-11.9231 \\
1.6350 \\
-9.1289 \\
5.5296 \\
7.395 \\
-2.7298
\end{array}\right\} .
$$

The element $V_{\text {int }}$ is the average market price of the object of evaluation, which is 76.34 thousand UAH. Taking into account the inherent features of analogs, the price of technology of servo conversion of DC has changed due to the levels of signs of the R\&D product: competitiveness - reduced by 4.56 thousand UAH; technological readiness - increased by 11.23 thousand; knowledge intensity - reduced by 1.83 thousand UAH; legal protection - increased by 1.8 thousand $\mathrm{UAH}$; key competencies of the development team - reduced by 14.13 thousand UAH; social orientation - increased by 8.45 UAH; environmental friendliness - increased by 3.04 thousand; security - reduced by 11.92 thousand UAH; scaling capacity - increased by 1.63 thousand UAH; the potential for market convergence - reduced by 9.12 thousand UAH. Risk is increased by 5.52 thousand UAH; market diffusion - discounted by 7.39 thousand UAH; the complexity of the market launch - reduced by 2.72 thousand UAH.

A positive or negative value of the obtained indicators shows the corresponding dynamics of their influence.
Thus, based on the results obtained, we can conclude about the nature of the consumer value and market receptivity of the analyzed $R \& D$ product, since they integrate i the corresponding signs of factors influencing the price of the R\&D productnto their composition. For example, indicators that in solution (5) have a negative value, in particular: competitive ability, knowledge intensity, key competencies of the development team, security, market convergence potential, market diffusion, and the complexity of the R\&D product market launch indicate the risks inherent to $R \& D$ products from the relevant attributes of these influencing factors.

Similar calculations were made for other types of R\&D products of LLC "Diada Group”. Practical results confirm the fact that the method allows you to get more accurate results in terms of the average market price of an R\&D product. Certainly, the set of factor signs influencing the price of an $R \& D$ product may change, depending on the type of $R \& D$ product and changing market conditions. Therefore, this method is more flexible for pricing purposes, compared to the known ones. This method allows you to quickly adjust the price of an $R \& D$ product, in accordance with changes in market conditions, and even the R\&D product warehouse. Based on this, the method can be used for pricing in the short and medium-term. In the case of using the method for the purposes of strategic pricing can have errors, because the changing market conditions are leveled.

The model of providing pricing for R\&D products based on the method for forming the price of an R\&D product taking into account its consumer value and market receptivity, as well as tools for determining the average market price for an R\&D product allows you to compare the adjusted price of an $R \& D$ product with the average market price and set the optimal level of the required price. The results of calculations carried out on the example of R\&D products of LLC "Diada Group" are summarized in Table 3.

Reading of the results showed that the price set by LLC "Diada Group" for the technology of DC servo conversion is 67.45 thousand UAH. The calculations show that the technology is characterized by a fairly high indicator of consumer value $(\mathrm{H}-34.9)$, due to a significant level of innovation of the components, as well as a high indicator of market receptivity. The price correction factor for this R\&D product is $18.4 \%$. Therefore, the price of this technology can be increased to 79.86

Table 3

Comparison of prices for R\&D products of LLC "Diada Group”, obtained by the authors' methods, with average market prices of analogs

\begin{tabular}{|c|c|c|c|c|c|c|c|c|}
\hline \multirow[b]{2}{*}{ No } & \multirow[b]{2}{*}{$\mathrm{R} \& \mathrm{D}$ products } & \multirow{2}{*}{$\begin{array}{l}\text { Price of R\&D } \\
\text { product, } \\
\text { thousand } \\
\text { UAH/unit }\end{array}$} & \multicolumn{2}{|c|}{$\begin{array}{l}\text { The value of linguistic terms of the factor } \\
\text { influencing the price of } R \& D \text { product }\end{array}$} & \multirow{2}{*}{ 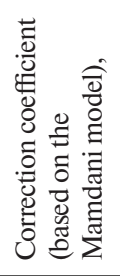 } & \multirow{2}{*}{ 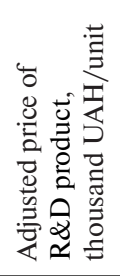 } & \multirow{2}{*}{ 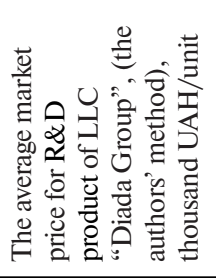 } & \multirow{2}{*}{ 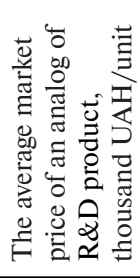 } \\
\hline & & & $\begin{array}{l}\text { features that } \\
\text { determine the } \\
\text { consumer value of } \\
\text { R\&D product }\left(x_{1}\right)\end{array}$ & $\begin{array}{l}\text { features that } \\
\text { determine the } \\
\text { market receptivity of } \\
\text { R\&D product }\left(x_{2}\right)\end{array}$ & & & & \\
\hline 1 & $\begin{array}{l}\text { DC servo conversion } \\
\text { technology } \\
\text { (XDX-200 series) }\end{array}$ & 67.45 & H (34.9) & $\mathrm{H}(35)$ & +18.40 & 79.87 & 76.34 & 84.50 \\
\hline 2 & $\begin{array}{l}\text { The device of } \\
\text { smooth start, a series } \\
\text { of SSB (model } \\
\text { SSB-21-170) }\end{array}$ & 32.71 & A (21.3) & $\mathrm{M}(8.7)$ & +3.26 & 33.78 & 35.60 & 50.12 \\
\hline 3 & $\begin{array}{l}\text { The device of } \\
\text { smooth start, a series } \\
\text { of SSB (model } \\
\text { SSB-21-210) }\end{array}$ & 47.57 & A (12.6) & E $(-5.4)$ & -1.03 & 46.14 & 45.13 & 40.20 \\
\hline 4 & $\begin{array}{l}\text { DM series magnetic } \\
\text { plate control device } \\
\text { (model DM-12-1) }\end{array}$ & 10.27 & $\mathrm{H}(41.2)$ & $\mathrm{M}(-0.1)$ & +2.14 & 10.41 & 12.50 & 16.80 \\
\hline
\end{tabular}


thousand UAH. The possibility of increasing the available price for this technology is also confirmed by applying the authors' approach to the formation of the average market price, for which the value obtained was 76.34 thousand UAH. Both possible prices for the analyzed $\mathrm{R} \& \mathrm{D}$ product are lower than the market price of the analogs -84.5 thousand UAH. That is, LLC "Diada Group" can increase the current price for the technology of DC servo conversion (for example, to the proposed level of 79.87 or 76.34 thousand UAH.) because the technology is successfully accepted by the market and has a high level of consumer value, which provides it with competitive advantages. Accordingly, the company will have a higher level of profitability. Further increase in the price, for example, to the level of the average market price of analogs (84.5 thousand UAH), should be studied on the basis of demand flexibility.

The described situation is also typical for devices from positions 2 and 4 in Table 3. As for the soft start device, SSB series (model SSB-21-210), the current price is 47.57 thousand UAH. It should be reduced by 1.03 , that is, to the level of 46.14 thousand $\mathrm{UAH}$, or the level of 45.13 thousand UAH - to the received average market price of the $R \& D$ product. The received prices remain higher than the market price of the ana$\log -40.20$ thousand UAH, but they are reasonable and will help to increase the competitive position of this device in the market of industrial electronics.

Conclusions. Increasing turbulence of innovative development actualizes the problem of developing tools to ensure relatively stable business functioning. In the economic sphere, this is happening in the background of the search for effective methods for determining the key performance indicators of innovative business, which, in particular, include $R \& D$ valuation methods. The authors' model of pricing for R\&D products is developed while carrying out the research. It is based on the methodology of forming the price of R\&D products taking into account its consumer value and market receptivity, the matrix method for forming the average market price of $R \& D$ products, and the approach to comparing the obtained showings with the prices of market analogs.

The hypotheses established to achieve the research aim were tested through the evaluation procedure of various $R \& D$ products that are produced by industrial electronics companies and whose products lay the technical and technological potential for the development of other industrial enterprises, including the mining industry.

Hypothesis 1 is true, since the method for pricing for the $\mathrm{R} \& \mathrm{D}$ product based on its customer value and market receptivity is developed based on Mamdani algorithm of fuzzy set theory, allows to formalize and to consider different parameters that define consumer value and market receptivity of the $R \& D$ product. The correction coefficient developed using this method contributes to the formation of a reasonable price for an R\&D product and is flexible in use. This method allows you to set the optimal price of $R \& D$ products in a changing market and therefore is important when making decisions on investment projects. The matrix method for determining the average market price for $\mathrm{R} \& \mathrm{D}$ products is relatively maneuverable compared to existing ones. It allows you to quickly adjust both the composition of $R \& D$ products features and, in fact, their prices, taking into account their inherent characteristics and market positions.

Hypothesis 2 is also true since the formed features of generalizing factors influencing the price of the $R \& D$ product are universal and can be applied in the pricing process of any industrial enterprises. At the same time, it should be noted that the set of features may vary depending on the type of $R \& D$ product and the specifics of the market in a particular period.

Hypothesis 3 is not fully true, since the developed model provides high performance mainly in the short and mediumterm. In the case of its use for the purposes of strategic pricing can have errors, because the changing market conditions are leveled. The price indicators obtained using the developed methodological support reflect the situation that is typical for the R\&D product and its competitors in a certain and analyzed period.

Acknowledgments. The authors express their gratitude to the head and development team of LLC "Diada Group" for obtaining valuable practical knowledge and providing information about technologies in the field of industrial electronics, as well as the necessary data for conducting this research.

\section{References.}

1. Schwab, K. (2019). The Global Competitiveness Report 2019. Switzerland: World Economic Forum. Retrieved from http:// www3.weforum.org/docs/WEF TheGlobalCompetitivenessReport2019.pdf.

2. IVSC (2020). International Valuation Standarts 2020. Retrieved from https://www.ivsc.org/files/file/view/id/1601.

3. TEGOVA (2020). European Valuation Standards 2020. Retrieved from https://www.tegova.org/en/p4912ae3909e49.

4. Borgs, C., Chayes, J., Chickering, D., Feige, U., Mahdian, M., Meek, C., \& Saberi, A. (2015). Price determination for items of low demand. Retrieved from https://portal.unifiedpatents.com/patents/patent/US-7627515-B2.

5. Morenoa, S., \& Epstein, D. (2019). The price of innovation the role of drug pricing in financing pharmaceutical innovation. A conceptual framework Journal of market access \& health policy, 2, 1-8. https://doi.org/10.1080/20016689.2019.1583536.

6. Chwastyk, P., \& Kolosowski, M. (2014). Estimating the Cost of the New Product in Development Process. Procedia Engineering, 69, 351-360. https://doi.org/10.1016/j.proeng.2014.02.243.

7. Barillas, F., \& Shanken, J. (2018). Comparing asset pricing models. The Journal of Finance, 73(2), 715-754. https://doi. org/10.1111/jofi.12607.

8. Matushevska, O. A., \& Katkova, N. V. (2017). Scientific and methodical approaches to forming the mechanism for ensuring the economic sustainability of industrial enterprises. Naukovyi Visnyk Natsionalnoho Hirnychoho Universytetu, (5), 123-131.

9. Kiselakova, D., Sofrankova, B., Cabinova, V., Onuferova, E., \& Soltesova, J. (2018). The Impact of R\&D Expenditure on the Development of Global Competitiveness within the CEE EU Countries. Journal of Competitiveness, 10(3), 3450. https://doi.org/10.7441/joc.2018.03.03.

10. Wang, M. Y. (2016). The valuation methods and applications for academic technologies in Taiwan. In 2016 Portland International Conference on Management of Engineering and Technology (PICMET), IEEE, (pp. 1320-1327). Honolulu, HI, USA. https://doi.org/10.1109/PICMET.2016.7806739.

11. Pylypenko, H., Fedorova, N., Hyzenko, I., \& Naumenko, N. (2020). Paradoxes of Economic Development: Science and Innovation in the Modern World. Naukovyi Visnyk Natsionalnoho Hirnychoho Universytetu, (2), 153-159. https://doi. org/10.33271/nvngu/2020-2/153.

12. Prokhorova, V., Korzh, R., Mrykhina, O., Koleshchuk, O., \& Mirkunova, T. (2019). Evaluation of Innovative Technologies in Conditions of the Digital Economics. International Journal of Recent Technology and Engineering (IJRTE), 8(3C), 230-236. https://doi.org/10.35940/ijrte.C1039.1183C19.

13. Prokhorova, V., Korzh, R., Mrykhina, O., Koleshchuk, O., \& Mirkunova, T. (2020). Innovative Technologies Under Digital Economics Conditions. International Journal of Advanced Science and Technology, 29(8s), 2504-2510.

14. Verkhovna Rada of Ukraine. Legislation of Ukraine (n.d.). Resolution of the Cabinet of Ministers of Ukraine "On approval of the National standard No. 4 "Assessment of property rights of intellectual property" dated 03.10.2007 No. 1185. Retrieved from https://zakon.rada.gov.ua/laws/show/1185-2007$\% \mathrm{D} 0 \% \mathrm{BF} \#$ Text.

15. State websites of Ukraine (n.d.). Decree of the State Property Fund of Ukraine "On approval of the Methodology for assessing property rights of intellectual property" dated 25.06.2008 No. 740. Retrieved from https://zakon.rada.gov.ua/laws/show/z0726$\underline{08 \# \text { Text. }}$ 


\section{Моделі вартісного оцінювання науково-технічних розробок промислових підприємств}

\section{Г. М. Пилипенко ${ }^{1}$, В. В. Прохорова ${ }^{2}$, О. Б. Мрихіна ${ }^{3}$,} О.Я. Колешук ${ }^{3}$, С. А. Мушнікова ${ }^{4}$

1 - Національний технічний університет «Дніпровська політехніка», м. Дніпро, Україна, e-mail: annapylyp@ukr.net 2 - Українська інженерно-педагогічна академія, м. Харків, Україна

3 - Національний університет «Львівська політехніка», м. Львів, Україна

4 - Національна металургійна академія України, м. Дніпро, Україна

Мета. Розробити модель ціноутворення на науково-технічні розробки промислових підприємств, що б відповідала умовам мінливості й нестабільності ринкового середовища.

Методика. Дослідження базувалося на сукупності методів, серед яких: компаративний аналіз, що був використаний для порівняння існуючих підходів до ціноутворення на R\&D products; алгоритм Mamdani теорії нечітких множин - для розробки методики формування ціни на R\&D products з урахуванням їх споживчої цінності й ринкової сприйнятливості; матричний метод - задля визначення рівня середньоринкової ціни на R\&D product.

Результати. Проаналізовані існуючі методичні підходи до ціноутворення на ринку науково-технічних розробок промислових підприємств, виділені їх переваги та обмеження. Розроблена методологія формування ціни на R\&D product, що дозволяє врахувати його споживчу цінність i ринкову сприйнятливість. Обгрунтовано матричний метод визначення рівня середньоринкової ціни на R\&D product. Проведене порівняння цін на R\&D products, отриманих на основі застосування авторського підходу, з цінами їх ринкових аналогів. Оцінено рівень вірогідності отриманих результатів на прикладі R\&D products TOB «Діада-Груп».

Наукова новизна. Розроблена модель ціноутворення на $R \& D$ products, що базується на методології формування ціни на R\&D product з урахуванням його споживчої цінності й ринкової сприйнятливості, матричному методі формування середньоринкової ціни R\&D products, підході до порівняння отриманих показників із цінами ринкових аналогів. На відміну від відомих, такий комплексний підхід дає змогу досягти вищого рівня точності ціни, оскільки враховується сукупність різнорідних ознак факторів впливу на ціну R\&D product (шляхом розробки коригувального коефіцієнту на засадах алгоритму Mamdani теорії нечітких множин). Підхід до формування ознак факторів впливу на ціну R\&D product уможливлює маневреність щодо оперування складом ознак R\&D product.

Практична значимість. Авторська модель ціноутворення на R\&D products пройшла апробацію на TOB «Діада-Груп» і продемонструвала високі можливості підвищення точності формування цін в умовах мінливого ринку. Будучи доволі гнучким інструментом ціноутворення, дана модель може бути застосована у практичній діяльності підприємств різних галузей економіки.

Ключові слова: науково-технічні розробки, моделі ціноутворення на $R \& D$ products, комерціалізація нововведень, конкурентоспроможність, наукоємність

\section{Модели стоимостной оценки научно- технических разработок промышленных предприятий}

\author{
А. Н. Пилипенко ${ }^{1}$, В. В. Прохорова ${ }^{2}$, О. Б. Мрыхина ${ }^{3}$, \\ О.Я. Колешук $\kappa^{3}$, С.А. Мушникова ${ }^{4}$
}

1 - Национальный технический университет «Днепровская политехника», г. Днепр, Украина, e-mail: annapylyp@ ukr.net

2 - Украинская инженерно-педагогическая академия, г. Харьков, Украина

3 - Национальный университет «Львовская политехника», г. Львов, Украина

4 - Национальная металлургическая академия Украины, г. Днепр, Украина

Цель. Разработать модель ценообразования на научнотехнические разработки промышленных предприятий, которая отвечала бы изменчивым условиям рыночной среды.

Методика. Исследование базировалось на совокупности методов, среди которых: компаративный анализ, который был использован для сравнения существующих подходов к ценообразованию на научно-технические разработки; алгоритм Mamdani теории нечетких множеств - для разработки метода формирования цены на научно-технические разработки с учетом их потребительской ценности и рыночной восприимчивости; матричный метод - для формирования среднерыночной цены на научно-технические разработки.

Результаты. Проанализированы существующие подходы к ценообразованию на рынке научно-технических разработок промышленных предприятий, выделены их преимущества и ограничения. Разработана методология формирования цены на научно-техническую разработку, которая позволяет учитывать ее потребительскую ценность и рыночную восприимчивость. Обоснован матричный метод определения среднерыночной цены на научно-техническую разработку. Проведено сравнение цен на научно-технические разработки, полученных при применении авторского подхода, с ценами их рыночных аналогов. Оценен уровень достоверности полученных результатов на примере научно-технических разработок ООО «Диада Групп».

Научная новизна. Разработана модель ценообразования на научно-технические разработки, которая базируется на методологии формирования цены на R\&D product с учетом ее потребительской ценности и рыночной восприимчивости, матричном методе формирования среднерыночной цены на научно-технические разработки, подходе к сравнению полученных показателей с ценами рыночных аналогов. В отличие от известных, такой комплексный подход позволяет достичь более высокого уровня точности цены, поскольку учитывается совокупность разнородных признаков факторов влияния на цену научно-технической разработки (путем разработки корректирующего коэффициента на основе алгоритма Mamdani теории нечетких множеств). Подход к формированию признаков факторов влияния на цену научно-технической разработки делает возможным маневрирование составом признаков научно-технической разработки.

Практическая значимость. Авторская модель ценообразования на научно-технические прошла апробацию на продукции ООО «Диада Групп» и продемонстрировала высокие возможности повышения точности формирования цен в условиях изменчивого рынка. Будучи достаточно гибким инструментом ценообразования, данная модель может найти применение в практической деятельности предприятий различных отраслей экономики.

Ключевые слова: научно-техническая разработка, модели ценообразования на $R \& D$ products, коммерциализация нововведений, конкурентоспособность, наукоёмкость

Recommended for publication by O.V.Tryfonova, Doctor of Economic Sciences. The manuscript was submitted 16.03.20. 